\title{
STUDI PENAMBAHAN KARAGENAN RUMPUT LAUT (Eucheuma cottonii) DALAM PEMBUATAN MIE BASAH BERBASIS TEPUNG SAGU (Metroxylon sp.)
}

Study of Sea Weed (Eucheuma cottonii) Addition of Wet-Based Noodle Based on Sago Flour (Metroxylon sp.)

\author{
Ode Kaudin, Andi Besse Patadjai, Kobajashi Togo Isamu \\ Jurusan Teknologi Hasil Perikanan, Fakultas Perikanan dan Ilmu Kelautan Universitas Halu Oleo, Kendari, \\ Sulawesi Tenggara, Indonesia \\ *Email korespondensi: kaudinode013@gmail.com (Telp: +6285349783024) \\ Diterima: 25 September/ Disetujui 20 Oktober 2019
}

Cara sitasi: Kaudin O, Patadjai AB, Isamu KT. 2019. Studi penambahan karagenan rumput laut (Eucheuma cottonii) dalam pembuatan mie basah berbasis tepung sagu (Metroxylon sp.). Jurnal Fish Protech. 2(2):251-259.

\begin{abstract}
The purpose of this study was to determine the effect of adding carrageenan to the sensory quality, proximate and physical quality of sago flour based wet noodles. This study used a Completely Randomized Design (CRD) using an experimental method with a concentration of $51 \%$ flour composite material, $41 \%$ sago flour with the addition of carrageenan consisting of three treatments, addition of carrageenan T0 (control 0\%), T1 (8\%), and T2 (10\%) and repeated three times. Data from observations were analyzed using ANOVA (Analysis of Variance) at a level of $95 \%$, if there is a real difference $(P>0.05)$ then a further test was performed with a DMRT (Duncan Multiple Range Test) test at a 95\% significance level. The results of the study were drawn from the best assessment results of the highest sensory value obtained in the T2 treatment with a color value of 5.13 , suppleness 7.20 , taste 7.73 , and aroma 6.23 . Proximate composition of wet noodles was obtained at T2 treatment, water content with a value of $35.94 \%$, protein content of $5.07 \%$, fat content of $1.39 \%$, ash content of $5.47 \%$, carbohydrate content of $31.45 \%$ and crude fiber content of $15,16 \%$. The physical quality of wet wet noodles can be obtained at T2 treatment, wet noodle development test with a value of $0.83 \mathrm{~mm}$ (milli meters) and water absorption test with a value of $1.04 \%$. The results showed that there was a significant influence on the addition of carrageenan to the proximate quality and physical quality of wet noodles but did not have a significant effect on sensory quality on the aroma attributes.
\end{abstract}

Keywords: Carrageenan, Wet noodles, Sago flour

\begin{abstract}
ABSTRAK
Tujuan penelitian ini adalah untuk mengetahui pengaruh penambahan karagenan terhadap kualitas sensorik, proksimat dan kualitas fisik mie basah berbasis tepung sagu. Penelitian ini menggunakan Rancangan Acak Lengkap (RAL) dengan menggunakan metode eksperimen dengan konsentrasi bahan komposit tepung terigu $51 \%$, tepung sagu $41 \%$ dengan penambahan karagenan yang terdiri dari tiga perlakuan, penambahan karagenan T0 (kontrol $0 \%), \mathrm{T} 1(8 \%)$, dan T2 (10\%) dan ulangan sebanyak tiga kali. Data hasil pengamatan dianalisa menggunakan ANOVA (Analysis of Variance) pada taraf $95 \%$, apabila terdapat beda nyata $(P>0,05)$ maka dilakukan uji lanjut dengan uji DMRT (Duncan Multiple Range Test) pada taraf nyata $95 \%$. Hasil penelitian diambil dari hasil penilaian terbaik dari nilai tertinggi sensorik yang diperoleh pada perlakuan T2 dengan nilai warna 5,13 , kekenyalan 7,20 , rasa 7,73 , dan aroma 6,23 . Komposisi proksimat mie basah diperoleh pada perlakuan T2, kadar air dengan nilai 35,94\%, kadar protein 5,07\%, kadar lemak $1,39 \%$, kadar abu $5,47 \%$, kadar karbohidrat $31,45 \%$ dan kadar serat kasar $15,16 \%$. Kualitas fisik mie basah basah dapat diperoleh pada perlakuan T2, uji pengembangan mie basah dengan nilai $0,83 \mathrm{~mm}$ (mili meter) dan uji daya serap air dengan nilai $1,04 \%$. Hasil menunjukkan bahwa terdapat pengaruh nyata penambahan karagenan terhadap kualitas proksimat dan kualitas fisik mie basah namun tidak memberikan pengaruh nyata terhadap kualitas sensorik pada atribut aroma.
\end{abstract}

Kata kunci: Karagenan, Mie basah, Tepung sagu 


\section{PENDAHULUAN}

Mie merupakan jenis makanan utama yang sudah dikenal dibeberapa negara asia. Pada umumnya di negara Asia terdapat variasi yang luas pada komposisi, metode pembuatan dan penyajian mie. Dalam perkembangannya, mie merupakan produk yang sangat dikenal di berbagai belahan dunia. Di Indonesia, mie telah banyak digemari oleh masyarakat luas baik dari anak-anak sampai orang dewasa. Selain itu, mie juga telah menjadi pangan alternatif utama setelah nasi. Hal ini tidak hanya disebabkan oleh rasanya yang enak dan nilai gizinya yang relatif tinggi, tetapi cara penyajiannya yang mudah dan praktis (Astawan, 1999).

Bahan-bahan yang umum digunakan dalam pembuatan mie adalah $\mathrm{NaCl}$, kansui (campuran antara natrium karbonat dan kalium karbonat). Bahan baku utama pembuatan mie adalah gandum sebagai bahan baku pembuatan tepung terigu yang memiliki konstribusi penting terhadap mutu mie. Mesda (2002), protein gluten yang terdapat pada pengadonan terigu dapat memberikan sifat elastis, struktur dan kemampuan menahan gas terhadap mie. Namun tepung terigu sebagai bahan dasar pembuatan mie masih impor sampai sekarang, sehinggga tepung terigu perlu disubstitusi dengan bahan lain yang ketersediaannya cukup melimpah di Indonesia. Salah satu cara alternatif tersebut adalah mengembangkan komoditas lain yang memiliki komposisi yang tidak jauh berbeda dengan tepung terigu. Bahan alternatif tersebut adalah tepung sagu.

Sagu (Metroxylon sp.) yang dimanfaatkan sebagai bahan baku mie merupakan salah satu jenis tanaman pangan dengan kandungan karbohidrat yang cukup tinggi tetapi sangat rendah kandungan protein, serat, lemak, dan abu. Di Indonesia, keberadaan sagu cukup melimpah dengan luas areal sagu secara nasional diperkirakan sudah mencapai 1 juta hektar sehingga jika jumlah pohon sagu sebanyak 25 pohon/hektar dan produktivitasnya $100 \mathrm{~kg}$ pati sagu kering/pohon maka dapat diperkirakan potensi sagu nasional mencapai 2,5 juta ton/tahun. Dengan potensi produksi sagu yang cukup tinggi tersebut maka sagu dapat digunakan sebagai sumber karbohidrat disamping mengganti beras sebagai makanan pokok (Rahim et al, 2009). Selain sagu, bahan alternatif lain untuk meningkatkan nilai gizi mie yang digunakan sebagai substitusi tepung terigu adalah karagenan.

Karagenan adalah polisakarida yang berantai linear atau lurus yang mempunyai molekul galaktan dengan unit-unit utamanya adalah galaktosa dan memiliki senyawa hidrokoloid yang terdiri dari ester kalium, natrium, magnesium, kalsium sulfat dan galaktosa, dengan 3,6 anhidro galaktokopolimer. Karagenan merupakan bahan alami pembentuk gel dan pengemulsi yang dapat digunakan untuk mengenyalkan mie dan bakso (Hope et al, 1979). Berdasarkan uraian diatas, maka diperlukan suatu penelitian mengenai studi penambahan karagenan rumput laut dalam pembuatan mie basah berbasis tepung sagu.

\section{METODE PENELITIAN}

\section{Alat dan Bahan}

Alat yang digunakan dalam penelitian ini teridiri antara lain, mixer, ayakan, sendok, cetakan mie, baskom, panci, gelas dan kompor. Peralatan untuk melakukan uji fisik adalah mistar/penggaris sedangkan peralatan untuk melakukan analisis kimia adalah cawan petri (pyrex), oven (memmert), desikator (equipment pharmacy), tanur (alabtech), cawan porselen (RRC), kompor listrik, gelas piala (iwaki pyrex), corong buncher (pyrex), labu penghisap (pyrex), gelas ukur (pyrex), gegep, dan spektrofotometer.

Bahan yang digunakan dalam pembuatan mie basah adalah bahan baku, bahan tambahan, dan bahan kimia untuk analisis mie basah. Bahan baku mie yang digunakan adalah tepung sagu yang diperoleh dari pedagang di kelurahan Kambu, Sulawesi Tenggara dan karagenan diperoleh di Toko Indogrosir Anduonohu Kendari, Sulawesi Tenggara. Bahan tambahan mie yang digunakan meliputi telur, garam, soda kue, air, minyak nabati dan Carboxy Methyl Cellulosa (CMC). Bahan kimia untuk keperluan 
analisis adalah asam sulfat pekat, Natrium hidroksida, Cu kompleks, asam borat, dietil eter, Asam klorida,

\section{Parameter Uji}

Cara menentukan penilaian sensori terhadap produk mie basah yang meliputi warna, kekenyalan, rasa dan aroma. Pengujian menggunakan 20 orang panelis (Lolopayung et al, 2019).

Pengamatan analisis uji fisik meliputi uji daya serap air (Muhajir, 2007) dan uji daya pengembangan (Aisya et al, 2014) sedangkan pengamatan analisis uji proksimat meliputi kadar air AOAC (1995). Kadar serat kasar (Sudarmadji et al, 2007). Kadar abu (AOAC, 2005). Kadar protein (AOAC, 2005). Kadar lemak (AOAC, 2005). Kadar karbohidrat (AOAC, 2005).

\section{Rancangan Penelitian}

Rancangan penelitian yang digunakan adalah Rancangan Acak Lengkap (RAL) dengan menggunakan metode eksperimen dengan konsentrasi bahan komposit tepung terigu $51 \%$, tepung sagu $41 \%$ dengan penambahan karagenan yaitu: $T_{0}$ : Tepung terigu $51 \%$ : Tepung sagu $41 \%$ : karagenan $0 \%, \mathrm{~T}_{1}$ : Tepung terigu $51 \%$ : Tepung sagu $41 \%$ : Karagenan $8 \%, \mathrm{~T}_{2}$ : Tepung terigu $51 \%$ : Tepung sagu $41 \%$ : Karagenan 10\%. Masing-masing perlakuan diulang sebanyak tiga kali sehingga diperoleh 9 unit percobaan. alkohol, Natrium dioksida, aquades, tisu, kertas saring, $\mathrm{H}_{2} \mathrm{SO}_{4}$ dan alkohol.

\section{Pembuatan Mie Basah}

Pembuatan mie basah diawali dengan menimbang bahan-bahan yaitu bahan baku berupa tepung terigu, tepung sagu dan karagenan sesuai dengan kebutuhan dalam setiap perlakuan. Kemudian bahan tambahan berupa, telur $16 \%$, garam $2 \%$, CMC $2 \%$, soda kue $3 \%$ dan air $32 \%$ dicampurkan ke dalam adonan sesuai perlakuan sampai telihat rata di dalam baskom, adonan diulenin sampai terbentuk adonan yang kalis/sempurna. Adonan kalis dibulatkan lalu ditutup plastik dan didiamkan \pm 5 menit. Setelah itu penipisan adonan dengan alat pembuat mie dimulai dari ukuran ketebalan terbesar sampai terkecil dengan pengulangan 6 sampai 7 kali. Pada akhir proses pembentukan lembaran, adonan yang tipis dipotong memanjang selebar 2 mili meter dengan roll pemotong mie sampai terbentuk untaian mie. Mie basah yang telah jadi diletakan pada lembaran plastik transparan yang telah di taburi tepung terigu kurang lebih 10 gram. Mie direbus selama 3 menit pada suhu $100{ }^{\circ} \mathrm{C}$ dan ditambahkan 15 gram minyak goreng.

\section{Analisis Data}

Data yang diperoleh dianalisis dengan menggunakan sidik ragam (Analysis of variance atau Anova) dan apabila sidik ragam menunjukan perbedaan nyata, maka dilanjutkan dengan uji Duncan Multiple Range Test (DMRT) pada taraf nyata 95\% $(a=0,05)$.

\section{HASIL DAN PEMBAHASAN \\ Hasil \\ Uji sensorik}

Hasil rerata analisis sensorik mie basah meliputi penilaian warna, Aroma, kekenyalan, dan rasa dapat disajikan pada Tabel 1.

Tabel 1. Rerata Analisis attribute sensorik mie basah

\begin{tabular}{ccccc}
\hline \multirow{2}{*}{ Atribut Sensorik } & Perlakuan & Rerata nilai \pm SD & Kategori & DMRT 0,05\% \\
& & & & \\
\hline \multirow{2}{*}{ Warna } & T0 & $3,93^{\mathrm{a}} \pm 0,25$ & Agak coklat & \\
& T1 & $4,10^{\mathrm{a}} \pm 0,52$ & Agak Puth & $2=1,08$ \\
& T2 & $5,13^{\mathrm{b}} \pm 0,20$ & Lebih Puth & $3=1,14$ \\
\hline
\end{tabular}


ISSN : 2621 - 1475

Studi Penambahan Karagenan Rumput Laut (Kaudin et al.,)

J. Fish Protech 2019, Vol. 2 No. 2

\begin{tabular}{ccccc}
\hline \multirow{3}{*}{ Aroma } & T0 & $5,53^{\mathrm{a}} \pm 0,25$ & Agak tercium & \\
& T1 & $5,46^{\mathrm{a}} \pm 0,45$ & Agak tercium & - \\
& T2 & $6,23^{\mathrm{a}} \pm 0,40$ & Agak tercium & - \\
\hline \multirow{3}{*}{ Kekenyalan } & T0 & $1,40^{\mathrm{a}} \pm 0,26$ & Tidak kenyal & \\
& T1 & $5,60^{\mathrm{b}} \pm 0,43$ & kenyal & $2=1,37$ \\
& T2 & $7,20^{\mathrm{c}} \pm 0,60$ & Sangat kenyal & $3=1,44$ \\
\hline \multirow{2}{*}{ Rasa } & T0 & $2,70^{\mathrm{a}} \pm 0,20$ & Tidak terima rasa & \\
& T1 & $4,93^{\mathrm{b}} \pm 0,45$ & Terima rasa & $2=1,23$ \\
& T2 & $7,73^{\mathrm{c}} \pm 0,50$ & Sangat terima rasa & $3=1,29$ \\
\hline
\end{tabular}

Keterangan: Angka-angka yang diikuti oleh huruf yang sama menunjukkan tidak berbeda nyata dan huruf tidak sama menunjukan berbeda nyata berdasarkan uji DMRT 0,05 taraf kepercayaan $95 \%$.

T0 : tepung terigu $51 \%$ : tepung sagu $41 \%$ : karagenan $0 \%$

$\mathrm{T} 1$ : tepung terigu $51 \%$ : tepung sagu $41 \%$ : karagenan $8 \%$

T2 : tepung terigu $51 \%$ : tepung sagu $41 \%$ : karagenan $10 \%$

\section{Uji Fisik}

Hasil rerata analisis uji fisik mie basah meliputi penilaian uji daya serap air dan uji daya pengembangan mie basah dapat disajikan pada Tabel 2.

Tabel 2. Rerata Analisis uji fisik mie basah

\begin{tabular}{cccc}
\hline Uji Fisik & Perlakuan & Rerata \pm SD (\%) & DMRT 0,05 \% \\
\hline \multirow{2}{*}{ Daya Serap Air } & T0 & $0,94^{\mathrm{a}} \pm 0,15$ & - \\
& T1 & $0,94^{\mathrm{a}} \pm 0,15$ & - \\
\hline \multirow{3}{*}{ Daya Pengembangan } & T2 & $1,04^{\mathrm{b}} \pm 0,31$ & - \\
& T0 & $0,33^{\mathrm{a}} \pm 0,57$ & \\
& T1 & $0,66^{\mathrm{b}} \pm 0,11$ & $2=0,66$ \\
& T2 & $0,83^{\mathrm{c}} \pm 0,57$ & $3=0,83$ \\
\hline
\end{tabular}

Keterangan: Angka-angka yang diikuti oleh huruf yang sama menunjukkan tidak berbeda nyata dan huruf tidak sama menunjukan berbeda nyata berdasarkan uji DMRT 0,05 taraf kepercayaan 95\%.

T0 : tepung terigu $51 \%$ : tepung sagu $41 \%$ : karagenan $0 \%$

$\mathrm{T} 1$ : tepung terigu $51 \%$ : tepung sagu $41 \%$ : karagenan $8 \%$

T2 : tepung terigu $51 \%$ : tepung sagu $41 \%$ : karagenan $10 \%$

\section{Uji Proksimat Mie Basah Terbaik}

Hasil analisis uji proksimat produk mie basah terbaik diperoleh pada perlakuan T2 (10\% karagenan) dapat disajikan pada Tabel 3.

Tabel 3. Analisis uji proksimat produk mie basah terbaik (T2) 10\% Karagenan

\begin{tabular}{clc}
\hline \multirow{2}{*}{ No } & \multicolumn{1}{c}{ Komponen } & Kode sampel \\
\cline { 3 - 3 } & & T2 (10\% Karagenan) \\
\hline 1 & Kadar air & $35,94 \%$ \\
3 & Kadar protein & $5,07 \%$ \\
4 & Kadar lemak & $1,39 \%$ \\
5 & Kadar karbohidrat & $5,47 \%$ \\
6 & Kadar serat kasar & $31,45 \%$ \\
\hline
\end{tabular}

Keterangan : T2 = tepung terigu $51 \%$ : tepung sagu $41 \%$ : karagenan $10 \%$ 


\section{Pembahasan}

\section{Warna}

Hasil perhitungan rerata sensorik aroma berdasarkan Tabel 1 analisa attribute sensorik menunjukan pengaruh nyata. Hal ini diduga oleh adanya pigmen fikoeritin, fikosianin dan selulosa yang terdapat pada karagenan. Imeson (2000) menyatakan bahwa kelebihan selulosa dapat menyebabkan menjadi keruh, cara untuk menghilangkan kekeruhan karagenan dapat dilakukan dengan cara penyaringan dengan tujuan mengurangi kandungan selulosa pada karaginan sehingga warna yang dihasilkan menjadi cerah dan putih. Warna karaginan yang lebih putih akan mempermudah dalam aplikasi produk khususnya produk pangan. Selain itu, Pembentukan warna pada produk mie basah dengan perbedaan bahan baku dapat mempengaruhi komposisi bahan penyusunnya. Menurut Sjahmien Moehyi (1992), Warna pada suatu makanan khususnya mie basah memang berperan sekali dalam penampilan makanan. Hal ini sesuai dengan pernyataan Winarno (2004), warna merupakan parameter pertama yang menentukan tingkat penerimaan panelis terhadap suatu produk sehingga warna yang terkandung dalam mie basah dapat disebabkan oleh beberapa sumber, yaitu adanya pigmen, karamelisasi, reaksi mailard dan adanya perbedaan pencampuran bahan baku pada proses pengolahan mie basah.

\section{Aroma}

Hasil perhitungan rerata sensorik aroma berdasarkan Tabel 1 analisa attribute sensorik menunjukan pengaruh tidak nyata agak begitu kuat tercium dan diterima oleh panelis disebabkan oleh komposisi karagenan yang beragam disetiap perlakuan karena karagenan memiliki sifat kenetralan dalam produk mie sehingga karagenan tidak memberikan pengaruh signifikan terhadap aroma mie basah. Selain itu, pembuatan mie basah menggunakan bahan tambahan telur dan soda abu dapat berpengaruh terhadap aroma mie yang dihasilkan. Penggunaan tepung terigu juga dalam adonan dapat menutupi aroma yang enak setelah perebusan mie basah. Menurut Pangesti (2009) mengatakan bahwa proporsi soda abu dan telur berpengaruh terhadap aroma mie basah. Sehingga aroma yang khas telur pada mie basah dapat menyebabkan semakin berbeda dengan aroma yang ditimbulkan pada setiap perlakuan mie basah dimana telur berfungsi untuk mengikat senyawa volatil atau molekul yang mudah menguap. Menurut Kurniawati dan Fitriyono (2012), aroma telur yang terdapat pada mie basah disebabkan oleh aktivitas enzim lipoksigenase yang dapat menghidrolisis asam lemak tak jenuh ganda dan menghasilkan senyawa-senyawa volatil yang menyebabkan mie basah beraroma khas telur, khususnya etil fenil keton.

\section{Kekenyalan}

Hasil perhitungan rerata sensorik aroma berdasarkan Tabel 1 analisa attribute sensorik menunjukan pengaruh nyata. Hal ini diduga oleh pengaruh kombinasi proporsi pencampuran bahan antara tepung terigu dan karagenan. Karena faktor yang mempengaruhi kekenyalan mie basah yaitu kandungan gluten pada tepung terigu dapat menyebabkan mie basah menjadi lebih elastis dan dipengaruhi oleh sifat karagenan sebagai pembentuk gel dari hasil interaksi antara protein glutenin dan gliadin. Semakin banyak penambahan karagenan maka mie basah semakin meningkat kekenyalanya. Karena hal ini disebabkan karagenan mampu membentuk gel dalam pembuatan mie basah. Semakin banyak penambahan terigu dan karagenan maka mie basah semakin meningkat kekenyalanya, kekentalan, kehalusan, dan kekerasan. Deman (1997) menyatakan bahwa kualitas mie basah dipengaruhi oleh tekstur yaitu kehalusan, kekentalan, kekenyalan, dan kekerasan. Semakin banyak karagenan pada mie basah maka dapat meningkatkan kekenyalan mie basah. Sjahmien Moehyi (1992) menyatakan bahwa kekenyalan mie basah dapat kenyal disebabkan oleh jumlah karagenan lebih banyak dibandingkan dengan sagu, karena karagenan dapat membentuk gel yang baik sehingga dapat mengenyalkan mie basah. 


\section{Rasa}

Hasil perhitungan rerata sensorik aroma berdasarkan Tabel 1 analisa attribute sensorik menunjukan pengaruh nyata. Hal ini diduga rasa oleh pengaruh kombinasi proporsi pencampuran bahan antara tepung terigu dan karagenan. Karena faktor yang mempengaruhi rasa mie basah yaitu kandungan gluten pada tepung terigu dan dipengaruhi oleh sifat karagenan sebagai pembentuk gel dari hasil interaksi antara protein glutenin dan gliadin. Semakin banyak penambahan terigu dan karagenan maka mie basah semakin meningkat kekenyalanya, kekentalan, kehalusan, dan kekerasan. Deman (1997) menyatakan bahwa kualitas sangat terima rasa dipengaruhi oleh tekstur yaitu kehalusan, kekentalan, kekenyalan, dan kekerasan. Semakin tinggi konsentrasi karagenan maka rasa mie basah dapat disukai oleh panelis. Karena hal ini disebabkan karagenan mampu membentuk gel dalam pembuatan mie basah.

\section{Uji Daya Serap Air}

Hasil perhitungan rerata uji daya serap air berdasarkan Tabel 2 analisa uji fisik mie basah menunjukan pengaruh nyata terhadap perlakuan T2. $\mathrm{Hal}$ ini diduga penambahan karagenan dapat menyerap air menunjukan berpengaruh nyata sehingga perubahan bentuk mie pada proses perebusan dapat disebabkan oleh pengaruh kandungan protein pada mie karena karagenan mampu berinteraksi dengan makromolekul yang bermuatan protein sehingga mampu meningkatkan viskositas, membentuk gel dan lain-lain. Hasil interaksi karaginan protein sangat bergantung pada $\mathrm{pH}$ larutanya dan $\mathrm{pH}$ isoelektrik protein. Menurut Nurhadi dan Nurhasana (2010), pada tingkat penambahan air dalam jumlah yang sama, tepung yang memiliki kandungan protein tinggi mempunyai daya serap air lebih besar dari pada tepung dengan kandungan protein rendah. Semakin tinggi kandungan protein adonan, semakin lama waktu masak yang dibutuhkan.

\section{Uji Daya Pengembangan}

Daya pengembangan pada mie basah merupkan sifat kemampuan mie setelah mie basah menyerap air dalam proses sebelum dan setelah perebusan. Selain itu, daya pengembangan juga dapat menunjukan perubahan bentuk mie basah dalam proses perebusan. Pengukuran daya pengembangan mie basah dilakukan dengan mengukur diameter mie basah mentah sebelum di rebus pada 3 tempat berbeda pada setiap perlakuan, kemudian sampel di masukan kedalam air (mie mentah direbus) $80^{\circ} \mathrm{C}$ selama 2 menit kemudian sampel diukur kembali diameter mie basah pada 3 tempat yang berbeda (Aisya et al, 2014). Menurut Mustakim, et al. (2016), pada tingkat penambahan air dalam jumlah yang sama dapat meningkatkan daya pengembangan mie basah, tepung yang memiliki kandungan protein tinggi mempunyai daya serap air lebih besar daripada tepung dengan kandungan protein rendah. Semakin tinggi kandungan protein maka akan semakin lama waktu masak yang dibutuhkan.

Hasil perhitungan rerata uji daya serap air berdasarkan Tabel 2 analisa uji fisik mie basah menunjukan pengaruh nyata terhadap perlakuan $\mathrm{T} 2$. Hal ini diduga penambahan karagenan dapat menyerap air dengan jumlah tertentu dan mampu berinteraksi dengan makromolekul yang bermuatan sehingga dapat membentuk mie basah menjadi elastis. Misalnya protein, sehingga karagenan mampu mempengaruhi peningkatan viskositas (Winarno, 1996). Mekanisme terjadinya oleh bahan-bahan pengisi secara umum adalah akibat penyerapan air oleh bahan pengisi tersebut. Karagenan berperan sebagai gel protein yang sederhana, tidak berinteraksi langsung dengan matriks protein maupun mempengaruhi formasi protein tersebut (Suzuki, 1981).

\section{Kadar Air}

Hasil perhitungan rerata uji proksimat berdasarkan Tabel 3 menunjukan pengaruh nyata terhadap perlakuan T2. Hal ini disebabkan daya serap air pada karagenan, dimana protein memerlukan air lebih banyak sehingga dapat menyimpan gas 
sebanyak-banyaknya. Pada proses pembuatan mie basah terjadi gelatinisasi pati yang diawali dengan penyerapan air dan pembengkakan granula pati sehingga amilosa keluar dari granula pati. Hal ini sesuai pernyataan Mustakim et al. (2016), kandungan kadar air dipengaruhi oleh pati yang terdapat dalam bahan bakunya dimana pati dapat menyerap air sehingga mie yang diperoleh mengandung kadar air yang tinggi. Granula pati dapat menyerap air dan membengkak tetapi tidak dapat kembali seperti semula (Khomsatin, 2011). Menurut Mulyani (2015), perbandingan amilosa dan amilopektin akan mempengaruhi sifat kelarutan dan derajat gelatinisasi pati. Semakin besar kandungan amilopektin maka pati akan lebih basa, lengket dan cenderung sedikit menyerap air. Sebaliknya jika kandungan amilosa tinggi, maka pati bersifat kering, kurang lekat dan mudah menyerap air.

\section{Kadar Lemak}

Hasil perhitungan rerata uji proksimat berdasarkan Tabel 3 menunjukan pengaruh nyata terhadap perlakuan T2. Hal ini diduga karena semakin banyak penambahan karagenan maka kadar lemak mie basah dapat mengalami penurunan, hal ini sesuai pernyataan Nugroho et al. (2014) dalam penelitianya mengatakan bahwa penambahan karagenan bakso udang dengan kosentrasi $8 \%$ sebesar $0,22 \%$ menunjunkan penambahan karagenan mengalami penurunan kandungan lemak bakso udang. Menurut Abubakar (2011), karagenan merupakan serat alami yang menunjukan sifat hipokolestrolemik (penurunan kadar kolestrol) yang bermanfaat untuk mengurangi resiko mendapatkan serangan jantung. Hal ini sangat sesuai dengan minat masyarakat akhir-akhir ini yang lebih memilih makanan dengan kadar kolestrol rendah. Menurut Astawan (2006), lemak memberikan rasa gurih, sebagai pelarut vitamin, memperbaiki tekstur dan cita rasa bahan pangan. Penurunan cita rasa pada mie basah menunjukan penurunan kadar lemak. Menurut Winarno (2002) menyatakan bahwa lemak adalah suatu esrter asam lemak dengan gliserol yang berbentuk padat dalam suhu kamar, tidak mempunyai ikatan rangkap sehingga mempunyai titik lebur yang tinggi.

\section{Kadar Protein}

Hasil perhitungan rerata uji proksimat berdasarkan Tabel 3 menunjukan pengaruh nyata terhadap perlakuan T2. Hal ini diduga karena semakin banyak penambahan karagenan maka kadar protein mie basah dapat mengalami penurunan, akan tetapi penurunan tersebut tidak dipengaruhi oleh bertambahnya konsentrasi karagenan. Menurut Abubakar (2011), kadar protein dipengaruhi oleh jumlah dan jenis tepung yang digunakan sebagai bahan baku serta kandungan protein dari bahan tambahan yang digunakan. Karagenan tidak mempengaruhi kadar protein karena merupakan polisakarida. Karagenan dapat berikatan dengan protein menjadi proteokaragenat sehingga memperbesar luasan permukaan yang dapat menyerap atau mengikat air.

\section{Kadar Abu}

Hasil perhitungan rerata uji proksimat berdasarkan Tabel 3 menunjukan pengaruh nyata terhadap perlakuan T2. Hal ini diduga karena semakin banyak penambahan karagenan maka dapat meningkatkan kandungan mineral pada mie basah. Hal ini sesuai pernyataan Harris et al, (1989), semakin banyak karagenan yang digunakan cenderung meningkatkan kadar abu pada mie yang dihasilkan. Tingginya kadar abu mie dengan penambahan karagenan dipengaruhi oleh unsur-unsur mineral seperti kalsium, zat besi dan fosfor sehingga semakin tinggi penambahan karagenan kadar abu mie semakin meningkat (Subandiyono, 2009). Hal ini berbeda dengan penelitian Cipto et al. (2016), kadar abu kukis semakin rendah seiring dengan meningkatnya penambahan karagenan sebaliknya, kadar abu akan semakin tinggi seiring dengan meningkatnya penambahan tepung terigu dalam pembuatan kukis. Tinggi rendahnya kadar abu dipengaruhi oleh perbedaan kandungan mineral yang terdapat dalam bahan baku (Mustakim et al, 2016). 


\section{Kadar Karbohidrat}

Hasil perhitungan rerata uji proksimat berdasarkan Tabel 3 menunjukan pengaruh nyata terhadap perlakuan T2. Hal ini diduga karena penambahan tepung komposit lebih besar kosentrasinya dari pada karagenan. Tepung komposit merupakan kombinasi dari beberapa jenis tepung dengan komposisi tertentu. Dalam penelitian ini, bentuk tepung komposit yang digunakan adalah kombinasi tepung terigu, sagu dan karagenan. Penambahan kosentrasi tepung terigu dan sagu lebih tinggi dibandingkan kosentrasi karagenan maka kadar karbohidrat semakin tinggi. Hal ini sesuai pernyataan Kurniawati dan Fitriyono (2012), kadar karbohidrat depengaruhi komponen gizi lain, semakin tinggi kadar komponen gizi lain maka kadar karbohidrat akan semakin rendah.

\section{Serat Kasar}

Hasil perhitungan rerata uji proksimat berdasarkan Tabel 2 menunjukan pengaruh nyata terhadap perlakuan T2. Hal ini diduga karena semakin banyak penambahan karagenan terhadap tepung komposit maka dapat meningkatkan serat kasar pada mie basah, karena karagenan mampu berinteraksi kuat dengan amilosa tepung terigu dan sagu maupun protein, sehingga sebagian molekul karaginan cenderung lepas dari penyusun struktur mie, kemudian larut dalam air yang digunakan untuk merebus mie mentah selama proses pembuatan mie basah. pada penelitian Tomasik (2004) melaporkan penggunaan karagenan 1 dan 3\% dapat berpengaruh nyata terhadap peningkatan kadar serat mie karena karagenan memiliki sifat larut dalam air panas bila dibandingkan mie basah yang terbuat dari substitusi terigu dengan tapioca $20 \%$.

\section{KESIMPULAN}

Dari hasil dan pembahasan dapat disimpulkan :

1. Penambahan karagenan yang berbeda memberikan pengaruh nyata terhadap semua variabel sensori kecuali variabel aroma pada mie basah.
2. Penambahan karagenan yang berbeda memberikan pengaruh nyata terhadap uji fisik mie basah.

3. Penambahan karagenan yang berbeda memberikan pengaruh nyata terhadap variabel proksimat pada mie basah.

\section{DAFTAR PUSTAKA}

Astawan, M., Koswara, S. \& Herdiani, F. 2006. Pemanfaatan rumput laut eucheuma cottonii untuk meningkatkan kadar iodium dan serat pangan pada selai dan dodol. Jurnal Teknologi dan Industri Pangan, 15 (1): 61-69.

Astawan, M., 1999. Membuat Mie dan Bihun. Penebar Swadaya, Jakarta.

Aisya, B., Sri, W., dan Diding, S. 2014. Kajian Sifat Fisik Mie Basah Dengan Penambahan Rumput Laut. Jurnal Teknik Pertanian Lampung. Vol. 4. No. 2. Hal. 109.

AOAC. 1995-2005. Official Methods Of Analysis: AOAC Arlington.

Abubakar, Suryati, T., dan Aziz, A. 2011. Pengaruh Penambahan Karagenan terhadap Sifat Fisik, Kimia dan Palatabilitas Nugget Daging Itik Lokal (Anas platyrynchos). Semnas Teknologi Peternakan. IPB. Bogor.

Cipto, D., Raswen, E., dan Evy, R. 2016. Pemanfaatan Tepung Terigu Dengan Penambahan Rumpu Laut Dalam Pembuatan Cookies Dari Sukun. JOM Faperta. Vol. 3. No. 2. Hal. 1.12.

Deman, J.M. 1997. Kimia Makanan. ITB Press. Bandung.

Harris, R.S dan Karmas, E.1989. Evaluasi Gizi pada Pengolahan Bahan Pangan. ITB: Bandung.

Hope, H.A., Levring, T., and Tanaka, Y. 1979. Marine Algae in Pharmaceutical Science. dalam Kristianto. 1998. Isolasi dan karakterisasi Karagenan dari Rumput Laut Eucheuma sp. Imeson, A.P. (2000). Carrageenan. In Phillips, G.O. and Williams, P.A. (eds.). Handbook of Hydrocolloids. Cambridge. UK: Woodhead Publishing Limited. pp. 87-102. 
Kurniawati dan Fitriyono A. 2012. Pengaruh Subtitusi

Tepung Terigu Dengan Tepung Tempe dan

Tepung Ubi Jalar Kuning Terhadap Kadar

Protein, Kadar $\beta$-Karoten, dan Mutu

Organoleptik Roti Manis. Journal of Nutrition

College. Vol. 1 No.1. Hal : 344-351.

Moehyi, S. 1992. Penyelenggaraan Makanan Institusi dan Jasa Boga. Jakarta: Bharata.

Mustakim, Yusmarini, dan Netti, H. 2016.

Pemanfaatan Bubur Rumput laut dan Tepung

Sagu Dalam Pembuatan Mie Basah. Jom

Faperta. Vol. 3. No. 2. Hal. 1-15.

Mulyani, D. 2015. Kajian Mutu Mie Instan Yang

Terbuat Dari Tepung Jagung Lokal Riau dan

Pati Sagu. Skripsi. Fakultas Pertanian Universitas Riau. Pekanbaru.

Muhajir, A. 2007. Peningkatan Gizi Mie Basah dari Campuran Tepung Terigu dan Tepung Ubi Jalar Melalui Penambahan Tepung Tempe dan Tepung Ikan. Skripsi. Jurusan Teknologi Pertanian, Universitas Sumatera Utara. Medan.

Nurhadi, B., dan Nurhasana, S. 2010. Sifat Fisik Bahan Pangan. Widya Padjajaran. Bandung.

Mesda, B.M., 2002. Pencampuran Tepung Kasava dan Gluten serta Penambahan Kalsium Hidroksida sebagai Pengganti Bleng dalam Pembuatan Mie Kasava Basah. Skripsi.Fakultas Teknologi Pertanian, UGM, Yogyakarta.

Nugroho, A.N., Dewi, E.K., dan Romadhan, 2014. Pengaruh Perbedaan Konsentrasi Karagenan Terhadap Mutu Bakso Udang (Litopeneaus vannamei). Journal Pengolahan dan Bioteknologi Hasil Perikanan. Vol.3.No.4.Hal.59-64.

Pangesti, T., 2009. Pemanfaatan Pati Ganyong (Canna Edulis) Pada Pembuatan Mie Segar Sebagai Upaya Penganekaragaman Pangan Non Beras. Media pendidikan, Gizi dan kuliner. Vol 1, no.1

Rahim, A., Nova. W., dan Bisma. 2009. Sifat Fisikokimia dan Sensori Sohun Instan dari
Pati Sagu. Jurnal Argoland. Vol. 2. No. 16. Hal. 124-129.

Subandiyono. 2009. Bahan ajar nutrisi ikan protein dan lemak. Jurusan perikanan. Universitas Diponogoro Bandung.

Lolopayung S, Asnani, Isamu KT. 2019. Studi formulasi rumput laut (Kappaphycus alvarezii) dan tepung sagu (Metroxylon sp.) terhadap komposisi kimia, stabilitas dan sifat sensori pada produk cendol rumput laut. Jurnal Fish Protech. 2(1):1-10.

Tomasik, P., 2004. Chemical and Functional Properties Of Food Components Series. CRC Press, Boca Raton, Florida.

Winarno, F. G. 1996. Kimia Pangan dan Gizi. PT. Gramedia Pustaka Utama. Jakarta. 2002. Kimia Pangan dan Gizi. PT. Gramedia Pustaka Utama. Jakarta. 2004. Kimia Pangan dan Gizi. PT Gramedia Pustaka Utama: Jakarta. 